\title{
Implementation of Cabotage Principle in Indonesia Territory and Its Implication for Shipping: A Study from Law Perspective
}

\author{
Nurfaika Ishak ${ }^{1, a, *}$ and Meica Prameswari ${ }^{1, b}$ \\ ${ }^{1}$ Faculty of Law, University of Indonesia, Jakarta, Indonesia \\ ${ }^{2}$ Faculty of Law, University of Gadjah Mada, Jogjakarta, Indonesia \\ a.nurfaika.ishak@gmail.com, b.meicaprameswari@gmail.com \\ *corresponding author
}

Keywords: Cabotage principle, shipping, Indonesia, maritime law.

\begin{abstract}
Cabotage principle is a principle recognized in maritime law, especially in the shipping. The principle means that domestic shipping is entirely the right of the domestic state. Domestic state is entitled to forbid and restrict foreign vessel to sail and to conduct business in the area of the state (privilege). In this case, accordance with the sovereignty of each independent state, every vessel especially foreign flag vessel has to obtain a permit to across and to enter the territory of a state. Based on Indonesian regulation of Maritime Law and the Presidential Instruction No. 5 of 2005 concerning the Empowerment of the Shipping Industries, Indonesia has implemented and adopted the cabotage principle. Other regulation related with cabotage principle was maritime law No.17 of 2008 concerning the Shipping Law. The purpose of this study was to analyze factors that affect implementation of cabotage principle in Indonesia territory. The approach used is statute and conceptual approach. Then, the method used is case study which also talks about other country. The result of this research shows that concept of maintaining sovereignty of the state and promoting the national economy was a factor that become the background of implementation of the cabotage principle. Whereas, the inhibiting factors that affect implementation of cabotage principle such as the limitation of facilities and infrastructure, and the lack of human resources quality and quantity.
\end{abstract}

\section{Introduction}

The development of the sovereignty of a maritime country can be traced through the history of the international maritime law itself, where there is a battle between the two principles of the law of the sea, such as Res Nullius and Res Communis. According to the adherents of Res Nullius, the sea has no one, therefore it can be owned by every country that desires it. While the adherents of Res Communis argue that the sea is a common property of the world community, therefore it cannot be owned by all the country. In the practice of middle seaside states since ancient times this Res Communis principle was implemented by the kingdoms of Rhodia, Persia, Greece and Rome [1]. 
After the destroyed of the Roman empire, in the middle ages emerged new central waterfront states, each requiring a part of the sea which bordering their shores. This has led to the fact that the sea is no longer a common property (res communis). Medieval, Roman lawyers such as Bartolus and Baldus put forward the theory that divide the marine region into two parts: the sea under the rule of the coastal state, and the high seas free from the others authority and sovereignty of everyone [2].

The state's control of the sea is based on a legal conception, preceded by the passing of the rules of the 2nd-century Rodhian Sea Law, well received by all countries in the middle seaside [3]. Grotius a Dutchman in his book Mare Liberum or Freedom on the Sea stated that the sea is difficult to measure, so that the sea cannot be combined with the property of a nation or sea no one can have it because it will interfere with the freedom of other nations to use it. In fact, according to him, the sea is a source of wealth that is not spent (inexhaustable), therefore all nations are free to use it [4].

In the other hand, Grotius was opposed by Britishman John Salden and Pontanus from Denmark, stated there was no reason to said that the sea could not be owned by people, because that time England was known to be in control of a vast ocean with Portugal and Spain. Salden goes to say that it is very unreasonable to mention the unspeakable source of the ocean's resources. While Pontanus considers that sovereignty over the sea includes the extent of the authority to prohibit third parties from catching fish, while the right to sail should not be associated with ownership over the sea. According to Pontanus the sea can be divided into two parts, namely the sea adjacent to the coast (adacjent sea) which can be the property or sovereignty of the coastal state and its outer sea which should be regarded as open sea or high sea for any country that wishes to exploit it [5].

Comprehensive regulation of sovereignty and state jurisdiction in the sea began to be covered by four Geneva Conventions of 1958 governing territorial sea and additional zones, fisheries and conservation of biological resources on the high seas. Until the 1970's the four conventions were still considered sufficient to rules all human activities of the sea. The demand for a review of the conventions comes with the rapid development of marine based marine technology and the declining supply of marine biodiversity resources. In addition, the rate of shipbuilding technology is also one of the important factors causing the conventions to be considered inadequate. Another important factor is the increase of the number of newly independent states, thus generating new demands on the sea [6].

After a long negotiation, the 3rd member States of the 3rd Conference on the Law of the United Nations (UN) finally agreed on the United Nations Convention on the Law of the Sea, the United Nation Convention on the Law of the Sea, better known as UNCLOS 1982 which consists of 320 articles and 9 annexes. The Convention regulate all aspects of marine activity, such as delimitation, cross rights, pollution of the marine environment, marine scientific research, economic and trade activities, technology transfer and dispute resolution on maritime affairs. In accordance with article 308, this Convention shall enter into force on 16 November 1994, 12 months after the acceptance of the 60th ratification [7].

Geographically, the country of Indonesia is an archipelagic country that began to gain international recognition since the 1982 United Nations Convention on The Law of The Sea. The convention recognizes the concept of an archipelagic state or island nation. The existence of the convention contains provisions that the island state has sovereignty over all its territorial waters that enter into the archipelagic sections of the archipelago.

With the United Nations Convention on the Law of the Sea, the countries of the world began to have an universal law of the sea which developed into the national legal arrangements of states aimed at protecting the sovereignty of their country and to get the right and its obligations (utilizing marine resources and manage it), one of them is the application of Cabotage principle. 


\section{Ease of Use}

\subsection{Research Objectives}

General Objectives

This research aims to provide a more in-depth understanding of the issues of how is the Cabotage principle regulated under Indonesian law and what is the implication of the Cabotage principle in Indonesia.

\subsection{Significance of the Study}

The results of this study are expected to be useful for the application of the Cabotage principle in the Republic of Indonesia which is one of the largest maritime countrie in the world because Indonesia has the second longest coastline in the world after Canada, which is must be followed by the existing regulations. The existing regulations in the implementation of the Cabotage principle should not bring disaster to the Indonesian nation. Thats why, Indonesia should be improve better to be able achieve the balances of the demands of the international world. Development of Indonesian human resources also should be implemented by the Cabotage principle to promote the welfare state of Indonesia. In addition, the role of the government in providing decent infrastructure can be improved.

\section{Regulations of Cabotage Principles in Indonesian Law}

In Law Number 17 of 2008, the provisions on the principle of Cabotage is stipulated in the chapter on the transportation in the waters, in the section of sea transport mentioned that the type of transport consists of sea transport in the country, sea freight, special sea transport and sea-shipping sea transport.[8] The form of Indonesian state jurisdiction over sea transportation, that is with the application of the cabotage principle meaning that only Indonesian-flagged ships with manned crew of Indonesian nationality who make the voyage between islands or atar port within the territory of Indonesia.

According to the Maritime Encyclopedia, the Cabotage principle is the granting of privileges or privileges to the country-flagged ships concerned for the transport of goods and persons to be from / to the ports of the country concerned that the vessel concerned shall be owned or operated by a citizen or entity business established under the laws of that country and the ship concerned shall have the flag of that country [9]. The provisions on the use of Indonesian-flagged vessels by national sea transport companies are intended to implement the principle of Cabotage to protect the sovereignity and to support the realization of the Archipelagic Insight and provide the widest opportunity for the national sea transport company in obtaining the share of cargo [10].

Cabotage principle provides the power that the implementation of domestic shipping is entirely the right of the coastal state. That is, the coastal state reserves the right to ban foreign ships sailing and trading along the country's waters. The application of the Cabotage Principle is supported by the provisions of the Law of the International Sea, relating to the sovereignty and jurisdiction of the coastal state over its marine territory. Therefore, foreign ships should not be located or enter the territorial waters without permits and clear reasons. Except for line of aid vessels and have valid licenses or grounds without disturbing the stability of state security and order. Cabotage principle is rooted in the conception that the activity of domestic sea transport is part and strategic strength in maintaining the sovereignty of the state, thus the implementation of the Cabotage principle is not solely about economic issues or economic protection but is concerned with the issue of state 
sovereignty. With the provisions outlined in the 1982 Sea Law Convention, the coastal state has the sovereignty to exploit its maritime territory for the benefit of his country [11].

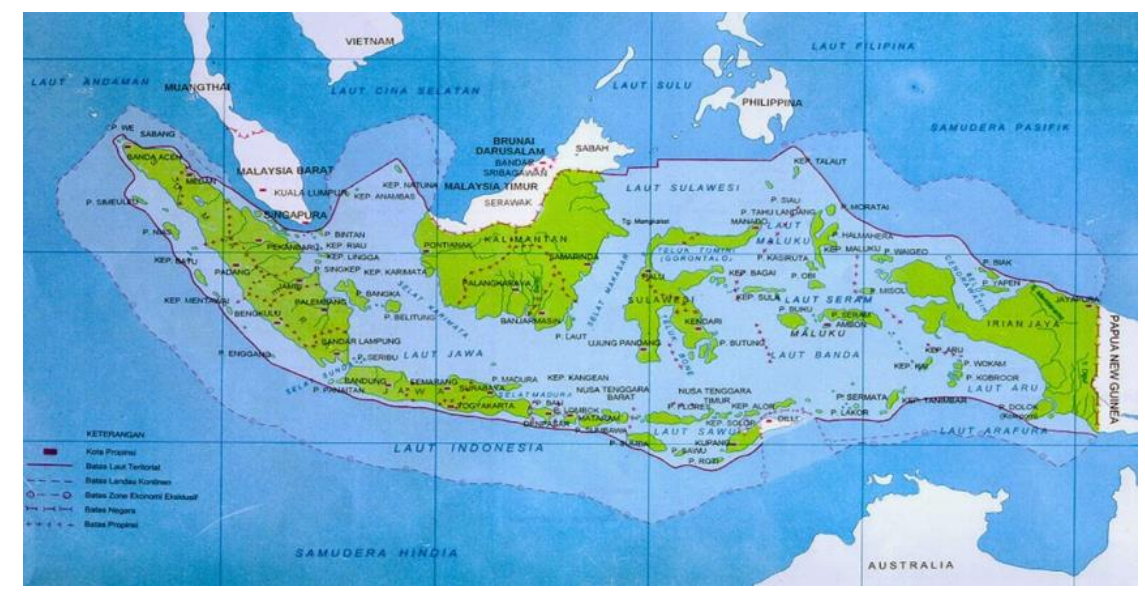

Figure 1: Map of Indonesia

While the definition of the Cabotage principle as conveyed by Mochtar Kusumaatmadja is the principle recognized in the laws and practices of shipping all over the world and is the embodiment of a country's sovereignty to take care of itself, in this case domestic transport, so it cannot simply be considered as protection that is protection or unfavorable privileges for domestic companies, resulting in unhealthy competition [12]. In addition, the principle of Cabotage is defined as the principle or principle which states that the shipping activities within the territorial waters of a country can only be done by the ships of the country concerned.

The implementation of this principle is intended to protect the sovereignty of the state and to support the realization of the Archipelagic Insight, as well as to provide the widest possible business opportunity for national sea transport companies in obtaining share of cargo. Such intentions as contained in the Elucidation of Law number 17 of 2008 on Shipping. In Indonesia the application of this principle has been declared successful, because up to 2014 there is an increase in the number of Indonesian flagged ships significantly. Cabotage Principles which imply that the conduct of domestic shipping is entirely the right of the coastal state. The coastal state reserves the right to prohibit foreign ships sailing and trading along the coast within the territorial waters of the coastal state. This principle is often referred to as a national trade voyage from one port to another within the territory of a country [13].

The purpose of the implementation of Indonesia's shipping system are [14]:

1. To facilitate the flow of people and / or goods through waters by prioritizing and protecting transportation in waters in order to accelerate national economic activities;

2. Nurture the soul;

3. Uphold the sovereignty of the state;

4. Create competitiveness by developing national water transport industry;

5. To support, mobilize, and encourage the achievement of national development objectives;

6. Strengthen the unity and unity of the nation in the context of the realization of the Archipelagic Insight;

7. Increase national resilience.

Arrangements for the field of transportation in the waters contain the principle of implementation of the Cabotage principle by means of empowering national sea transport which provides a conduciveness climate for advancing the transport industry in the waters, including the ease of taxation, and capital in the procurement of vessels and the existence of long-term contracts for 
transportation. The implementation of the strategic function can support the realization of the insight of the archipelago, increase exports and imports so as to increase foreign exchange revenue, and open employment opportunities, so that transport in the waters is controlled by the state whose implementation includes regulatory, controlling and supervision aspects. To achieve these objectives, the implementation of transport in the waters is implemented in several ways [15]:

1. To apply Cabotage principle consistently and consistently so that national water transport companies can be host in their own country;

2. Developing transport in waters for lagging areas and / or remote areas by shipping-pioneer and assignment;

3. To create a conducive business climate for the empowerment and independence of the national water transport industry;

4. Develop related service industries to support the smoothness of transport activities in the waters; and

5. Develop an integrated water transport information system that involves all related parties by utilizing the development of information and communication technology.

The enforcement of the Cabotage principle is affirmed with the provision that domestic sea transport activities are carried out by national sea transport companies using Indonesian-flagged vessels and manned by Indonesian citizenship Crew. This provision covers the possibility for foreign ships to undertake domestic sea transport activities, and hence foreign vessels are prohibited from transporting passengers and / or inter-island or interpassage goods in the territorial waters of Indonesia [16].

To prevent and mitigate environmental pollution and / or destruction resulting from the operation of ships and port activities and as a form of environmentally sound transportation, the Indonesian government considers it necessary to include the protection of the maritime environment as part of the shipping activities which constitute a unified system comprising for transport in waters, ports, as well as safety and security in the waters. The protection of the maritime environment includes [17]:

1. The prevention and control of pollution from the operation of the vessel;

2. Prevention and mitigation of pollution from port activities as well as industrial development and / or ship work;

3. Waste disposal in waters; and

4. Administrative sanctions.

\section{Cabotage Principle in Other Country}

As an archipelago, the philippines need efficient maritime transportation industry to achieve the growth and economic development as the sector an inclusive shipping connecting the islands and the economy in the philippines with international trade. Cabotage is traditionally a shipping term but it is now generally used to refer to the right to carry cargo or passenger via sea, air or land transport within a country. In the Philippine maritime transport sector, Cabotage is reserved only for national flag vessels by virtue of two laws-Republic Act (RA) 1937 or the Tariff and Customs Code of the Philippines and RA 9295 or the Domestic Shipping Development Act of 2004. The Philippines adopted the Cabotage Principle from the US Jones Act of 1920 when it was still under United States' colonial control. Republic Act 1937 enacted in 1957 continued the adoption of this principle [18].

Cabotage is basically a form of protection for Australian-registered ships. On economic efficiency grounds, there seems to no valid reason for continuing cabotage. This is particularly the case since protection for most industries has been wound back considerably. Cabotage can increase the cost to users of coastal shipping. Australian-registered ships generally have higher costs than 
foreign-flagged vessels partly because Australian ships have to comply with various pieces of legislation that foreign ships operating in the coastal trade do not have to meet. This is not to say that the legislation should be repealed: such legislation reflects Australian community standards. But it highlights the difficulties that Australian shipowners face in competing with foreign ships [19].

\section{Implications of Cabotage Principle Arrangement in Indonesia}

Transport in the waters has a very strategic function, namely to support the trade and economy activities (ship follows the trade) and stimulate the growth of the economy and the region (ship promotes the trade), so that transport in the waters serves as a strategic infrastructure for Indonesia as an archipelagic country. The implementation of the strategic function can support the realization of the insight of the archipelago, increase exports and imports so as to increase foreign exchange earnings of the state, and open employment opportunities, so that transport in the waters is controlled by the state whose implementation covers the aspects of regulation, control and supervision. In achieving that goal, the implementation of transport in the waters implemented in several ways:[20]

1. To apply consistent and consistent cabotage principle in order that the national water transport enterprise may become the host in its own country;

2. Developing transport in waters for lagging areas and / or remote areas by shipping-pioneer and assignment;

3. To create a conducive business climate for the empowerment and independence of the national water transport industry;

4. Develop related service industries to support the smoothness of transport activities in the waters; and

5. Develop an integrated water transport information system that involves all related parties by utilizing the development of information and communication technology.

Objectives to be achieved from the application of the cabotage principle, such as:[21]

1. Prevent and reduce dependence on foreign ships;

2. Streamlining the flow of goods or services and people to all regions of the archipelago widely;

3. One of the efforts of employment providers for citizens;

4. As reliable and supporting the National Defense and Security System.

Cabotage principle is part of the implementation of the sovereignty into a form of state coastal policy to restrict foreign ships entering its territory, especially inland water areas. Due to other territorial areas such as cross-country and additional zones the state is obliged to provide a peaceful passage for foreign ships, in accordance with the marine law convention / UNCLOS 1982.

The impact of successful cabotage principles, among others:[22]

1. Government

a. Strengthen state sovereignty;

b. Recruitment of domestic for crew shipping; and

c. Creation of national security.

2. Shipping Company

a. The magnitude of the domestic market share of the cargo loaded by national ships;

b. The high growth of the national economy and the growth of domestic cargo.

3. Indonesian National Ship Owners Association (INSA)

a. Increase The number of INSA members;

b. Domestic shipping companies are easy to monitor. 
Table 1: Implication of cabotage principle implementation.

\begin{tabular}{|l|l|l|}
\hline \multicolumn{1}{|c|}{ Indicator } & \multicolumn{1}{c|}{ Before } & \multicolumn{1}{c|}{ After } \\
\hline Defence and Security & Weak & Strong \\
\hline Shipping Industry & Stagnation & Increased \\
\hline
\end{tabular}

Table 2: Description of shipping industry category (insa.or.id [22]).

\begin{tabular}{|l|l|l|}
\hline \multirow{2}{*}{ Shipping Industry Category } & \multicolumn{2}{c|}{ Year } \\
\cline { 2 - 3 } & \multicolumn{1}{|c|}{2005} & \multicolumn{1}{c|}{2016} \\
\hline Number of Indonesian Vessels & 6.041 & 24.046 \\
\hline Total of Transport Capacity & 5.67 milion GT & 38.5 milion GT \\
\hline
\end{tabular}

The right of Cabotage in the actual sea transport (shipping) activities by developed countries in the era of globalization and free trade is still practiced, for example by the United States where under Article 14 Shipping Act, the American Minaret Until States and the Hawaiian Islands should only be done by US shipping companies only.[23]

State sovereignty over the sea can be interpreted as a right for the state to exercise control and management of the sea in order to be utilized as much as possible for the welfare and prosperity of the people. The effectiveness of state sovereignty at sea depends on the ability and capacity of the government in the maintenance and utilization of natural resources, especially at sea to further support the application of the role of all components of the nation in marine management.

Factors supporting the application of the Cabotage principle, among others:

1. Cabotage principle is a national sea transport company needs to encourage the growth of national marine transportation;

2. Establishment of a supervisory team to identify ships in charge of either controlling or supervising vessels operating in the territorial waters of Indonesia;

3. Facilitate the process of providing vessels by the government to support the licensing process and provide information required by the national marine transportation company;

4. Received loans from banks and financial institutions due to vessel procurement investment requires a relatively large cost.

Factors inhibiting the application of the Cabotage principle, such as:

1. The unavailability of ships with national flagstated for exploration and exploitation activities offshore;

2. Domestic shipping companies have not been able to provide certain types of ships to support offshore exploration / exploitation activities;

3. The cost of vessel procurement investment is very large;

4. The absence of long-term employment contracts between ship owners;

5. The low quality and quantity of human resources.

\section{Conclusion}

Cabotage principle provides the power that the implementation of domestic shipping is entirely the right of the coastal state. Thats mean, the coastal state have the right to ban foreign ships for sailing and trading in the country's waters. The application of the Cabotage Principle is supported by the provisions on the Law of the International Sea, related with sovereignty and jurisdiction of 
the coastal state over its marine territorial. Therefore, foreign ships should not be sailing or entering the territorial waters without permits from the coastal state.

Transport in the waters has a very fundamental function to support the trade and economy activities (ship follows the trade) and stimulate the growth of the economy and the region (ship promotes the trade). Therefore, transport in the waters serves as a strategic infrastructure for Indonesia as an archipelago. The implementation of the strategic function could support the realization of the insight of the archipelago, increase exports and imports to get increase foreign exchange earnings of the state, and open employment opportunities, so that transport in the waters is controlled by the state whose implementation covers the aspects of regulation, control and supervision.

State sovereignty over the sea can be interpreted as a right for the state to exercise control and management of the sea in order to be utilized as much as possible for the welfare and prosperity of the people.

\section{References}

[1] Hasyim Djalal, "Perjuangan Indonesia di Bidang Hukum Laut," Bandung: BPHN and Binacipta, p.11, 1979.

[2] Mochtar Kusumaatmadja, "Hukum Laut Internasional,” Bandung:Binacipta, p.2, 1978.

[3] Syamsumar Dam, "Politik Kelautan”, Jakarta: Bumi Aksara, p.12, 2010.

[4] Mochtar Kusumaatmadja, “Hukum Laut Internasional,” p 12.

[5] Syamsumar Dam, "Politik kelautan," p 5.

[6] Mochtar Kusumaatmadja and Etty R Agoe, “Pengantar Hukum Internasional,” Bandung: Alumni, p.170, 2003.

[7] Mochtar Kusumaatmadja and Etty R Agoe, "Pengantar Hukum Internasional," Bandung: Alumni, p.171, 2003.

[8] See Article 7 of Law no. 17 Year 2008 on Shipping.

[9] M Husseyn Umar, "Hukum Maritim dan Masalah-Masalah Pelayaran di Indonesia," Jakarta: PT. Fikahati Aneska, p 161, 2015.

[10] See Article 8 of Law no. 17 Year 2008 on Shipping.

[11] Muhammad Iqbal Asnawi, " Implikasi Pemberlakuan Asas Cabotage Dalam Pelayaran Nasional Terhadap Eksistensi Perusahaan Angkutan Laut Indonesia Pada Perdagangan Bebas Dalam Kerangka WTO”, Tesis, Magister, Universitas Sumatera Utara, Medan 2012.

[12] Mochtar Kusumaatmadja dalam Muhammad Iqbal Asnawi, "Implikasi Pemberlakuan Asas Cabotage Dalam Pelayaran Nasional Terhadap Eksistensi Perusahaan Angkutan Laut Indonesia Pada Perdagangan Bebas Dalam Kerangka WTO,” Medan: Universitas Sumatera Utara, p 19, 2012.

[13] M. Hussen Umar, "Hukum Maritim dan Masalah-Masalah Pelayaran di Indonesia", Book 2, Jakarta: Pusataka Sinar Harapan, p13, 2001.

[14] See Article 3 of Law no. 17 Year 2008 on Shipping.

[15] Explanation of Government Regulation Number 20 Year 2010 concerning Transportation in Waters in the General Paragraph.

[16] See Article 8 of Law no. 17 Year 2008 on Shipping.

[17] See explanation of Government Regulation no. 21 of 2010 on Maritime Environment Protection.

[18] See Gilberto M. Lianto and Adoracion M. Navarr, Relaxing the Cabotage Restrictions in Maritime Transport, Research Paper Commerce and Entrepreneurship, January 9, 2014, Senate Bill No. 1359

[19] See Richard Webb, Coastal shipping: an overview, Research Paper No.12 2003-04, Department of Parliamentary Services, Australia

[20] See explanation of general chapter of Government Regulation no. 20 of 2010 on Water Transportation.

[21] Mahmul Siregar and M Iqbal Asnawi, "Cabotage Principle Pada Regulasi Jasa Angkutan dalam Perairan Indonesia dari Prespektif Sistem Perdagangan Multilateral WTO/GATS," pg 19, 2012.. Another article: Balitbang Dephub RI, "Studi Penerapan Cabotage Principle dalam Pelayaran Nasional”, Laporan Akhir Penelitian, p 8, 2004.

[22] https://insa.or.id/asas-cabotage-demi-kedaulatan-negaral

[23] Rizki Aprilianto, et. al, "Implementasi Asas Cabotage Dalam Kebijakan Pelayaran di Indonesia”, Jurnal Administrasi Publik, Vol. 2, No.4. Universitas Brawijaya, p 762, 2014. 